BJHS: Themes 4: 293, 2019. C British Society for the History of Science 2019. This is an Open Access article, distributed under the terms of the Creative Commons Attribution licence (http:// creativecommons.org/licenses/by/4.0/), which permits unrestricted re-use, distribution, and reproduction in any medium, provided the original work is properly cited.

doi:10.1017/bjt.2019.16

\title{
Erratum
}

\section{Living collections: care and curation at Drosophila stock centres - ERRATUM}

\section{JENNY BANGHAM}

doi:10.1017/bjt.2019.14. Published online by Cambridge University Press, $16^{\text {th }}$ September 2019.

The above mentioned article by Jenny Bangham was originally published with an incorrect title and incorrect running heads.

This has now been updated in the online pdf and html versions of the article.

Reference:

Jenny Bangham, 'Living collections: care and curation at Drosophila stock centres', BJHS Themes (2019) 4, 123-147. doi:10.1017/bjt.2019.14 